\title{
MAXIMUM POWER POINT TRACKING CONTROL USING BOOST CONVERTER FOR A GRID-CONNECTED PV SYSTEM
}

\section{Dr. DANG DANH HOANG \& Dr. TRAN XUAN MINH*}

Thai Nguyen University of Technology, Vietnam

\begin{abstract}
ABTRACT
This paper presents a solution to design a control scheme for a grid-connected photovoltaic (PV) system to solve maximum power point tracking (MPPT) problem. The designed control structure solves the nonlinear problems in the model of the inverters. Simulation results demonstrate that the implemented control scheme can accurately control the grid-connected $P V$ system as required when an amount of radiation changes.
\end{abstract}

KEYWORDS: PV System, MPPT, P\&O algorithm, DC-DC converter, DC-AC converters.

Received: Jun 09, 2020; Accepted: Jun 29, 2020; Published: Sep 26, 2020; Paper Id.: IJMPERDJUN20201434

\section{INTRODUCTION}

Grid-connected PV systems have become popular in life. There are two commonly used converter types: On-Grid and Off-Grid. For off-grid converters, the system needs an energy accumulator, usually batteries. During the daytime, excess energy will be accumulated into the storage. At night time, the system will take energy from the storage to use. For On-Grid converters, the system does not need an energy accumulator but converts energy directly onto the grid. This system needs to perform a grid-tie requirement. A typical structure is depicted in Figure 1. The system structure includes a solar panel connected to a DC-DC converter, an inverter converting the received power to the grid, and a DC bus to pair these two components.

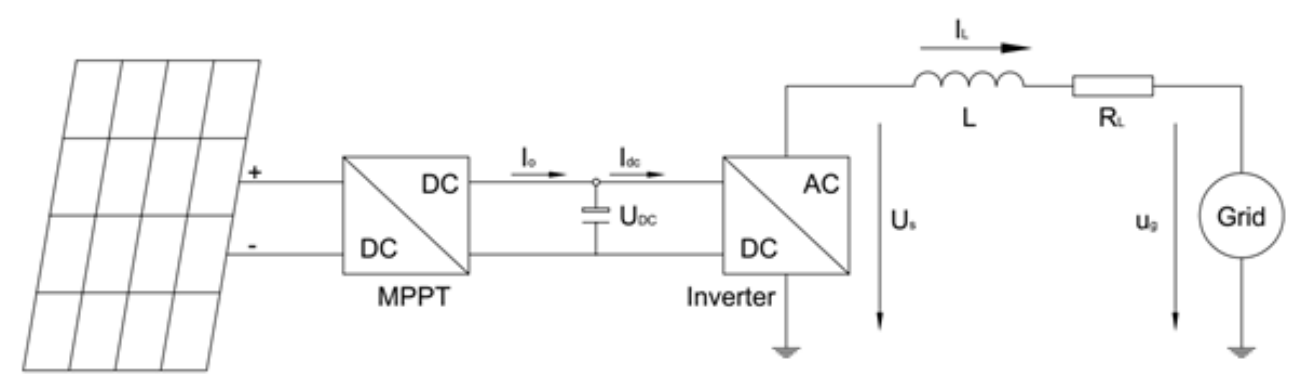

Figure 1: Structure of a PV On-Grid System

\section{MATHEMATICAL MODEL OF THE SYSTEM}

\subsection{Mathematical Model of the Solar Cell}

Solar cells operate according to the I-V and P-V nonlinear characteristics, which vary linearly with solar radiation and the operating temperature of the photovoltaic cell. General modeling of photovoltaic cells was presented in [1-5]. The equivalent diagram of the system is depicted in Figure 2a. The V- I equation for a photoelectric cell is determined as below: 


$$
\begin{array}{r}
I=I_{P H}-I_{S}\left[\exp \left(\frac{q\left(V+I R_{S}\right)}{k T_{c} A}\right)-1\right]-\frac{V+I R_{S}}{R_{S H}} \\
I_{P H}=I_{S C}^{S T C}+K_{i}\left(T_{P V}+T_{P V}^{S T C}\right) \frac{\lambda}{\lambda^{S T C}}
\end{array}
$$

The saturated current varies with the temperature of the photovoltaic cell, as determined by the following equation:

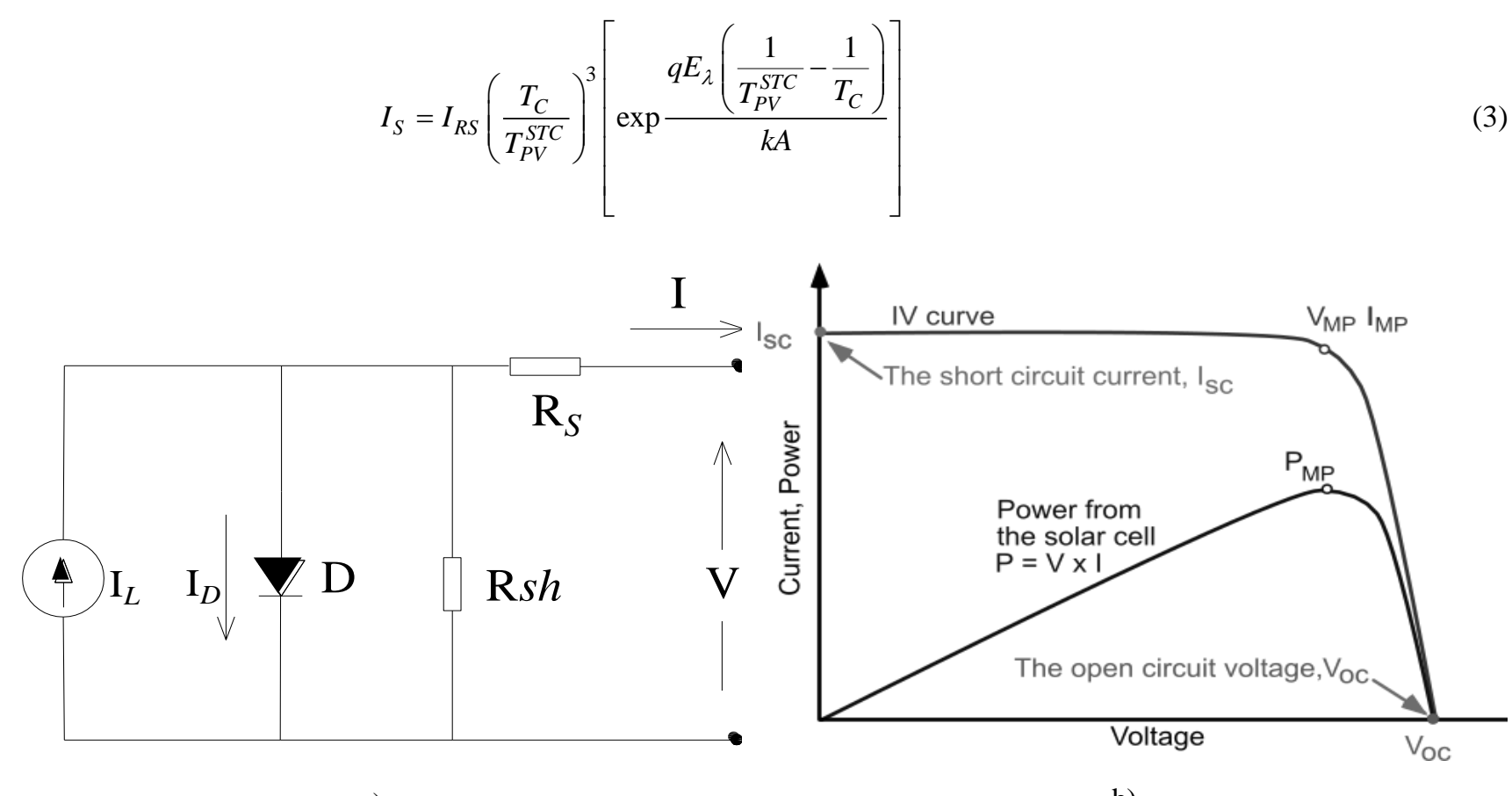

a)

b)

Figure 2: a) Equivalent diagram of Photovoltaic Cells; b) Working Characteristics of Solar Cell

The P-V characteristic of solar cells shows that it is necessary to use adjustment methods so that the working point of the panel reaches a maximum [6-8] to maximize the capacity of the system.

\subsection{Mathematical Models of the Boost}

Several structures of boost-typed DC-DC converter have been implemented for PV systems [9-11]. Various control methods have been introduced. However, the algorithms implemented in [9-11] are quite complex, requiring the system to perform a lot of calculations. In this paper, the DC / DC converter shown in Figure 1 is used as a boost [12].

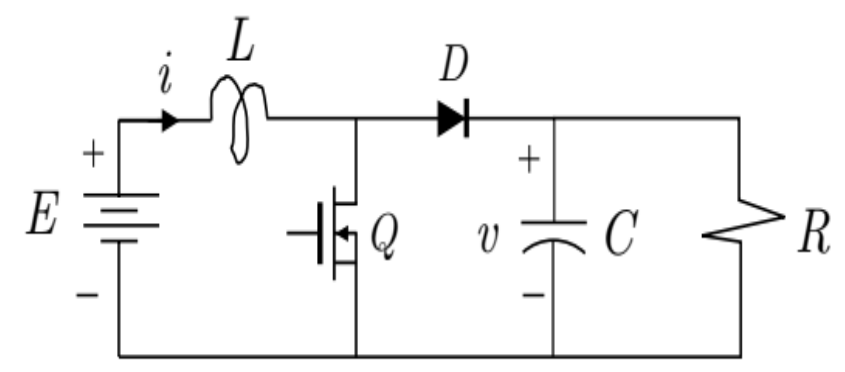

a) 


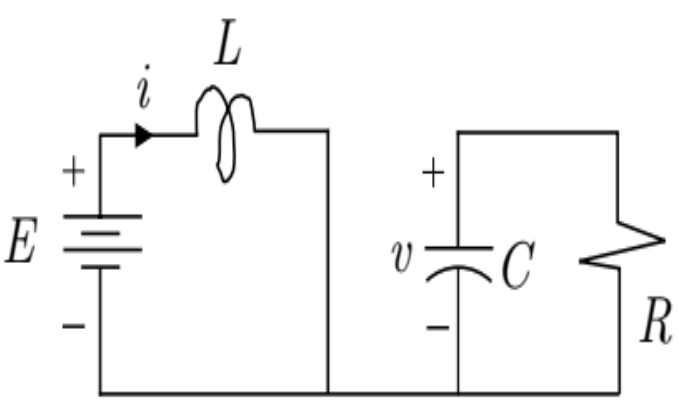

b)

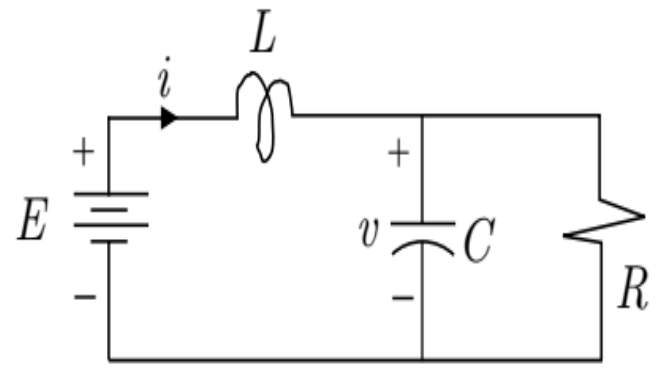

c)

Figure 3: The Structure and Working State of the Boost Converter

a) Boost converter structure

b) Working state when the valve is closed

c) Working state when the valve is open

The working states of the boost converter are shown in Figure 3. The boosters work with two states of the valve Q: ON or $\mathrm{OFF}$. When valve $\mathrm{Q}$ is on, the inductor is connected to the source $\mathrm{E}$, we have:

$$
L \frac{d i}{d t}=E
$$

The current variation of the inductor when the valve is closed $(\mathrm{ON})$ :

$$
\Delta I_{L_{-} \text {on }}=\frac{1}{L} \int_{0}^{D T} E d t=\frac{D T}{L} E
$$

When valve $\mathrm{Q}$ is opened (OFF), the coil is connected to the load, an equation describing the circuit is obtained as below:

$$
E-v=L \frac{d I_{L}}{d t}
$$

The current variation of the inductor during valve opening is described as follows:

$$
\Delta I_{\text {off }}=\int_{D T}^{T} \frac{E-v}{L} d t=\frac{(E-v)(1-D) T}{L}
$$

When the converter operates in a steady-state, the energy stored in the inductor at the beginning and the end of each cycle

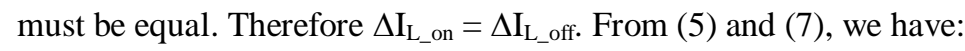

$$
\frac{D T}{L} E=\frac{(E-v)(1-D) T}{L} \Leftrightarrow E=v(1-D)
$$

Equation (8) describes the input voltage of boosters with the change of duty $\mathrm{D}$, in which $\mathrm{v}=\mathrm{U}_{\mathrm{DC}}$ is the $\mathrm{DC}$ bus voltage; $\mathrm{E}=$ $\mathrm{V}_{\mathrm{pv}}$ is the PV voltage. From (8) we have:

$$
V_{p v}=U_{D C}(1-D)
$$

Equation (9) describes the dependence of PV voltage on the duty D of the boost converter in a grid-connected PV system. 


\subsection{Mathematical Model of Grid-Connected Inverters}

The grid-connected inverter has the schematic diagram shown in Figure 1.

$$
\bar{U}_{L}=R \bar{I}_{L}+L \frac{d \bar{I}_{L}}{d t}+\bar{U}_{s}
$$

Equation of voltage across DC bus capacitors

$$
C \frac{d u_{d c}}{d t}=i_{o}-i_{d c}
$$

Project (10) on the dq rotation coordinate with the rotation angle of the voltage vector $\mathrm{u}_{\mathrm{d}}$

$$
\left\{\begin{array}{l}
\frac{d i_{d}}{d t}=-\frac{R}{L} i_{d}+\omega i_{q}-\frac{E_{d}}{L}+\frac{u_{d}}{L} \\
\frac{d i_{q}}{d t}=-\frac{R}{L} i_{q}-\omega i_{d}-\frac{E_{q}}{L}+\frac{u_{q}}{L}
\end{array}\right.
$$

On the other hand, the DC power is the AC consumption. Therefore,

$$
u_{d c} i_{0}=\frac{3}{2}\left(u_{S d} i_{d}+u_{S q} i_{q}\right)
$$

Applying $\mathrm{i}_{\mathrm{o}}$ from (13) into (14) yields:

$$
u_{d c}\left(C \frac{d u_{d c}}{d t}+i_{d c}\right)=\frac{3}{2}\left(u_{S d} i_{d}+u_{S q} i_{q}\right)
$$

From (12) and (14) we obtain:

$$
\left\{\begin{array}{l}
\frac{d u_{d c}}{d t}=\frac{3}{2} \frac{\left(E_{d} i_{d}+E_{q} i_{q}\right)}{C u_{d c}}-\frac{i_{d c}}{C} \\
\frac{d i_{d}}{d t}=-\frac{R}{L} i_{d}+\omega i_{q}-\frac{E_{d}}{L}+\frac{u_{d}}{L} \\
\frac{d i_{q}}{d t}=-\frac{R}{L} i_{q}-\omega i_{d}-\frac{E_{q}}{L}+\frac{u_{q}}{L}
\end{array}\right.
$$

The set of equations (15) describes the grid-connected converter on the dq coordinate system. In this model, we see a coupling between two dq axes. In order to implement system control, this coupling must be eliminated.

\section{DESIGN AND CONTROLS}

\subsection{DC-DC Converter Controller}

Two independent DC-DC and DC-AC converters are connected via the DC-Link bus. Therefore, the tuning of each converter can be considered independent. The output of the DC-DC converter is the input of the DC-AC converter, $U_{D C}$ is the output of the DC-DC converter, and $\mathrm{i}_{\mathrm{o}}$ is the input to the DC-AC converter.

The algorithm to find the maximum power point of a solar cell is based on the principle of output impedance adjustment to find the maximum power point of the panel. The most common algorithms are the $\mathrm{P} \& \mathrm{O}$ algorithm, incremental conductance, and fractional open-circuit voltage, in which the $\mathrm{P} \& \mathrm{O}$ algorithm is easily programmable. This algorithm can be implemented simply on microcontroller systems. Besides, assume that $\mathrm{U}_{\mathrm{DC}}=$ constant. From (9), we find that the boost 
converter input voltage $\mathrm{Vpv}$ is inversely proportional to duty $\mathrm{D}$.

Combined with the P\&O algorithm [15-17], we propose an algorithm summarized in Table 1 and Figure 4a

Table 1: The Operating Principle of the P\&O Algorithm

\begin{tabular}{|c|c|c|c|}
\hline $\begin{array}{c}\text { Variation of } \\
\text { Working Power } \\
(\mathbf{\Delta} \mathbf{P})\end{array}$ & $\begin{array}{c}\text { Variation of } \\
\text { Working Voltage } \\
(\mathbf{\Delta} \mathbf{V})\end{array}$ & $\begin{array}{c}\text { Working } \\
\text { Tendency of the } \\
\text { System }\end{array}$ & $\begin{array}{c}\text { Control } \\
\text { Tendency }\end{array}$ \\
\hline$\Delta \mathrm{P}<0$ & $\Delta \mathrm{V}<0$ & Position 1 & Increase Vref \\
\hline$\Delta \mathrm{P}<0$ & $\Delta \mathrm{V}>0$ & Position 2 & Decrease Vref \\
\hline$\Delta \mathrm{P}>0$ & $\Delta \mathrm{V}<0$ & Position 3 & Decrease Vref \\
\hline$\Delta \mathrm{P}>0$ & $\Delta \mathrm{V}>0$ & Position 4 & Increase Vref \\
\hline
\end{tabular}

The $\mathrm{P} \& \mathrm{O}$ algorithm is depicted in Figure $5 \mathrm{~b}$. Initialize the system with initial values $\mathrm{P}=0, \mathrm{~V}=0$; Solar panel voltage and current measurements are updated at the beginning of each calculation loop.

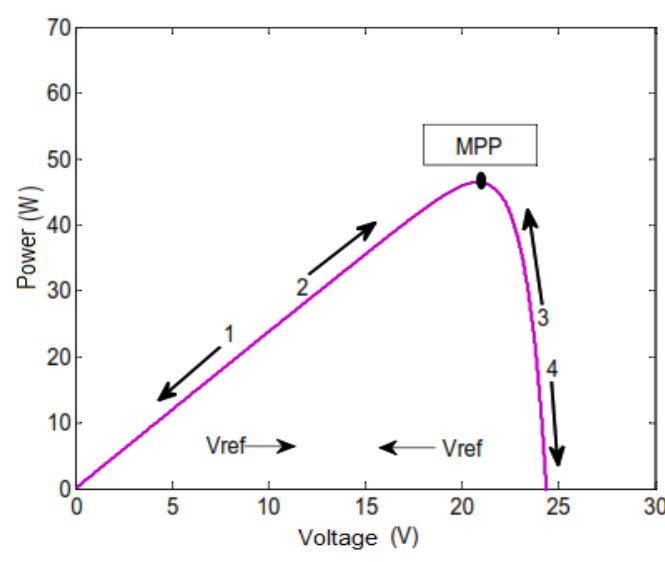

a)

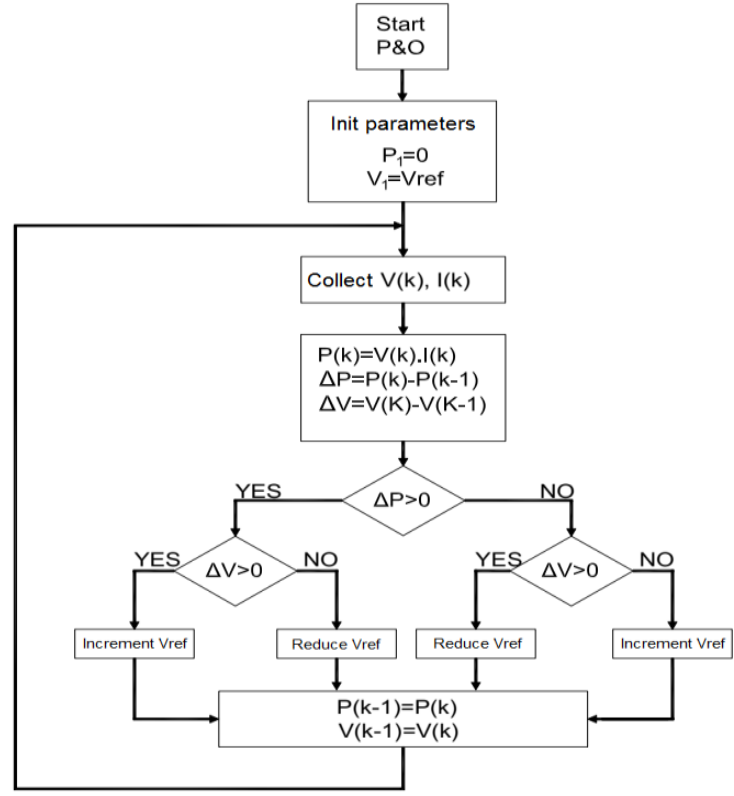

b)

Figure 4: a) P-V characteristic; b) The P\&O algorithm

Values used for control are voltage variation DV and power variation DP. If the voltage variation and the power variation are the same sign, duty D of the converter must decreases and vice versa. However, the increase or decrease of duty is not effective because the speed of change is slow. Even when the output voltage is less than the input voltage, the system cannot transmit the power. An added PI controller to speed up the convergence of the system is the solution to this problem.

\subsection{Grid-Connected Controller}

A method implemented for the grid-connected controller is the cascade controller [18-21], where the inner loop controls the current, and the outer loop controls the voltage. The goal of the grid-connected controller for the solar-cell system is to convert the PV power into the power consumed on the grid. Equation (14) shows that the power consumption P is related to two quantities $U_{D C}$ and $i_{d c}$. Therefore, the outer loop controller aims to keeps the $U_{D C}$ stable. 


\section{Current Controller}

Select control variables as follows

$$
\left\{\begin{array}{l}
\Delta u_{L d}=R i_{L d}+L \frac{d i_{L d}}{d t} \\
\Delta u_{L q}=R i_{L q}+L \frac{d i_{L q}}{d t}
\end{array}\right.
$$

Accordingly, (12) becomes

$$
\begin{aligned}
& u_{S d}=-\Delta u_{d}+\omega L i_{q}+u_{d} \\
& u_{S q}=-\Delta u_{q}-\omega L i_{d}+u_{q}
\end{aligned}
$$

By adding quantities containing components $i_{d}$ and $i_{q}$ that the system can suppress coupling, the control structure for the current loop is designed as shown in Figure 5

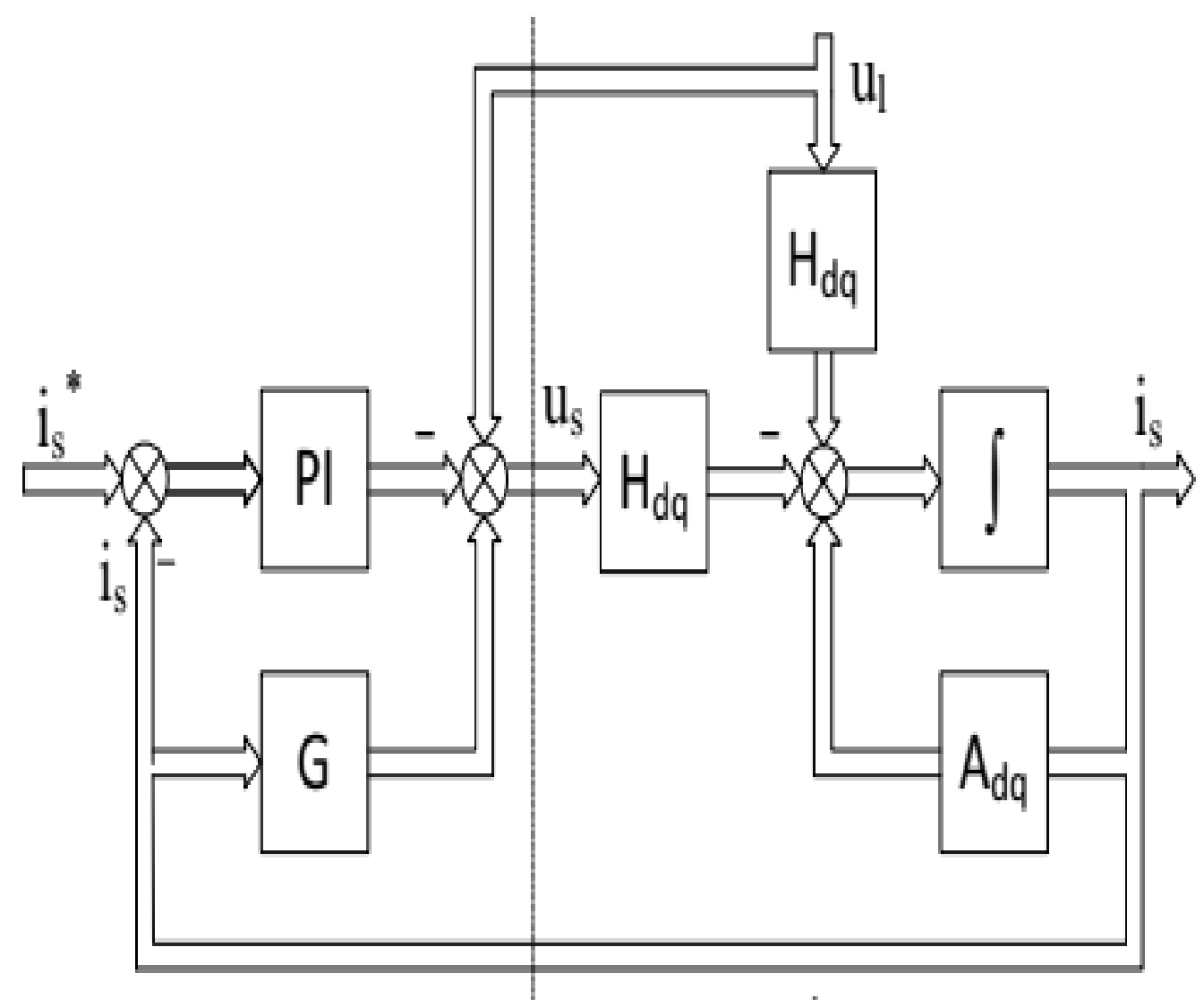

Figure 5: Structure of the Current Controller

where

$$
A=\left[\begin{array}{cc}
-\frac{R}{L} & \omega \\
-\omega & -\frac{R}{L}
\end{array}\right] ; H_{d q}=\left[\begin{array}{cc}
\frac{1}{L} & 0 \\
0 & \frac{1}{L}
\end{array}\right] ; G=\left[\begin{array}{cc}
0 & \omega L \\
-\omega L & 0
\end{array}\right]
$$


Consider the time constant of the converter $T_{\mathrm{sw}}=1 / \mathrm{f}_{\mathrm{sw}}$, where $\mathrm{f}_{\mathrm{sw}}$ is the carrier frequency. The transfer function of the inner current loop is:

$$
G_{i o}(s)=\frac{1}{\left(1+T_{s w} s\right)(R+L s)}
$$

Accordingly, we can apply the module optimization standard to find the parameters of the PI controller as follows:

$$
k_{p i}=\frac{L}{2 T_{s w}} ; T_{i i}=\frac{L}{R}
$$

The grid-connected inverter does not require the transmission of reactive power. Therefore the reference $\mathrm{i}_{\text {qref }}=0$. Accordingly, the control problem becomes voltage control, i.e. $\mathrm{U}_{\mathrm{dc}}=$ constant.

\section{Voltage Controller}

Elimination of the coupling effect has been performed at the current regulator. The $\mathrm{U}_{\mathrm{DC}}$ voltage regulator will provide the desired current value, $i_{\mathrm{d}}$. The transfer function of the voltage loop becomes:

$$
G_{u o}(s)=\frac{m}{C s} \frac{1}{1+2 T_{t} s}
$$

where $T_{t}$ is the sum of the time constants of the inner loop converter, $m$ is the amplification factor of the power electronic converter.

Synthesize the controller according to the symmetric optimization method, we can select parameters of the a PI controller as follows: $k_{p u}=\frac{1}{k T_{1} \sqrt{a}} ; T_{i u}=a T_{1}$

\section{SIMULATION RESULTS}

Simulation parameters are provided in Table 2 and Table 3.

Table 2: Parameters of the Solar Panels 1Soltech 1STH-215-P

\begin{tabular}{|l|l|l|l|l|}
\multicolumn{1}{|c|}{ Parameter } & \multicolumn{1}{c|}{ Unit } & \multicolumn{1}{c|}{ Value } & & \multicolumn{1}{c|}{ MPPT } \\
\hline Rated power & $\mathrm{P}_{\max }$ & $213.15 \mathrm{~W}$ & & $\mathrm{dV}=1 \mathrm{~V}, \mathrm{~T}_{\mathrm{s}}=10^{-4} \mathrm{~s}$ \\
\hline Open-circuit voltage & $\mathrm{U}_{\mathrm{oc}}$ & $36.3 \mathrm{~V}$ & & Boost Converter \\
\hline Short-circuit current & $\mathrm{I}_{\mathrm{sc}}$ & $7.84 \mathrm{~A}$ & & $\mathrm{~L}=0.1 \mathrm{H}, \mathrm{C} 1=0.1 \mathrm{uF}$ \\
\hline Voltage at maximum point & $\mathrm{V}_{\mathrm{mp}}$ & $29 \mathrm{~V}$ & & $\mathrm{k}_{\mathrm{p}}=0.35 ; \mathrm{k}_{\mathrm{i}}=10$ \\
\hline Current at maximum point & $\mathrm{I}_{\mathrm{mp}}$ & $7.35 \mathrm{~A}$ & & Inverter \\
\hline Number of serial panels & $\mathrm{N}_{\mathrm{s}}$ & 10 & & $\mathrm{U}_{\mathrm{dc}}=700 \mathrm{VDC} ; \mathrm{C}=6000 \mathrm{uF}$ \\
\hline Number of parallel panels & $\mathrm{N}_{\mathrm{p}}$ & 5 & & $\mathrm{~L}=10 \mathrm{mH} ;$ \\
\hline & & & & $\mathrm{k}_{\mathrm{pi}}=25 ; \mathrm{k}_{\mathrm{ii}}=100 ;$ \\
\hline & & & & $\mathrm{k}_{\mathrm{pu}}=0.2372 ; \mathrm{k}_{\mathrm{iu}}=62.5$ \\
\hline
\end{tabular}




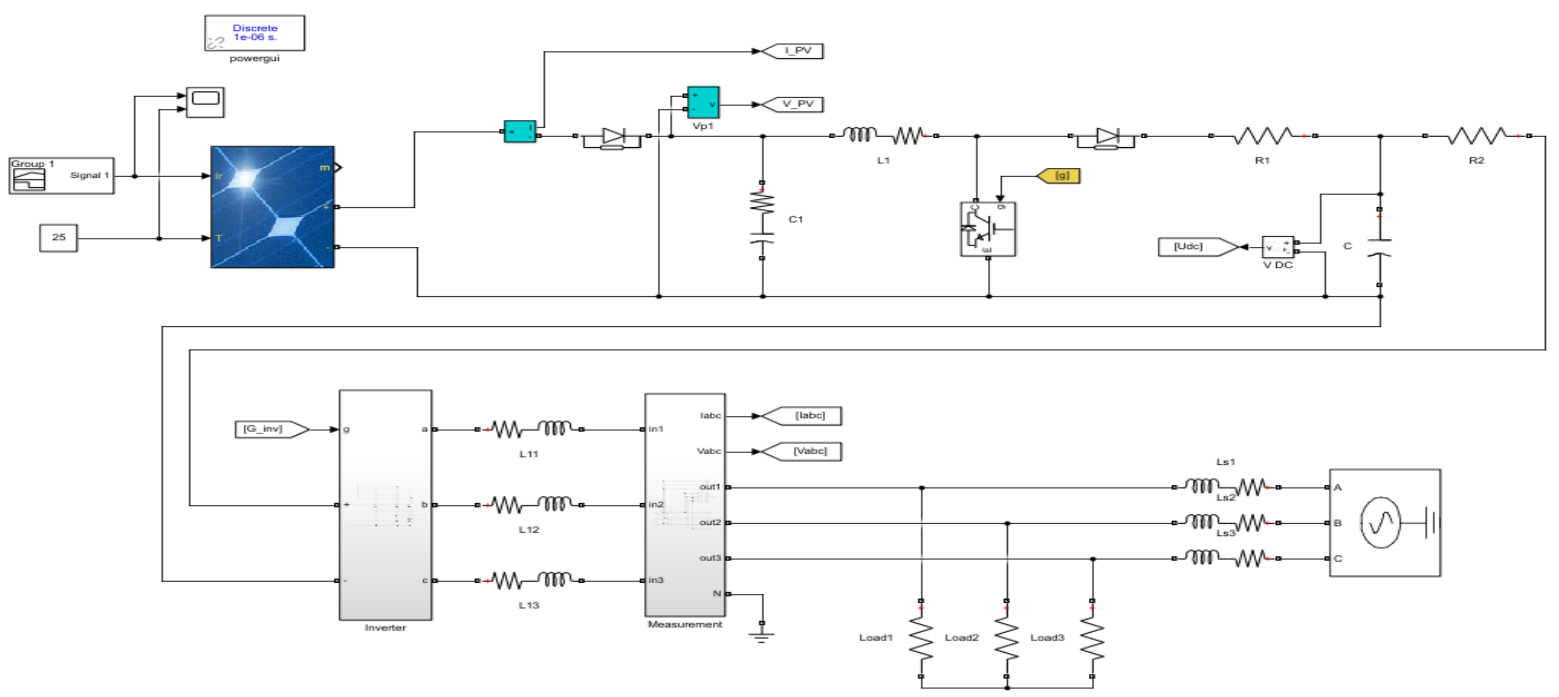

Figure 6: Simulation diagram

The simulation scenario is as follows: First, the solar radiation varies from $0 \mathrm{~W} / \mathrm{m}^{2}$ to $1000 \mathrm{~W} / \mathrm{m}^{2}$ in $0.1 \mathrm{~s}$, stands at this value for $0.5 \mathrm{~s}$. Then, the solar radiation changes from $1000 \mathrm{~W} / \mathrm{m}^{2}$ to $600 \mathrm{~W} / \mathrm{m}^{2}$ in $0.1 \mathrm{~s}$, stands at this value for $0.4 \mathrm{~s}$.

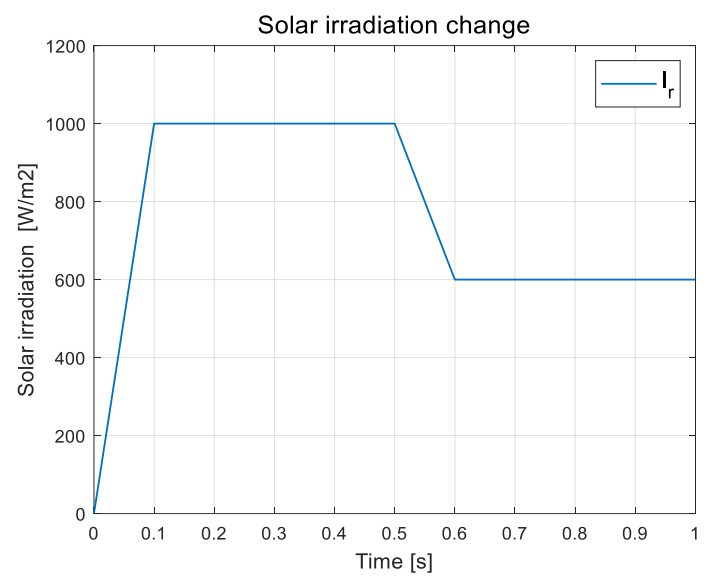

Figure 7: Change in the Radiation Intensity

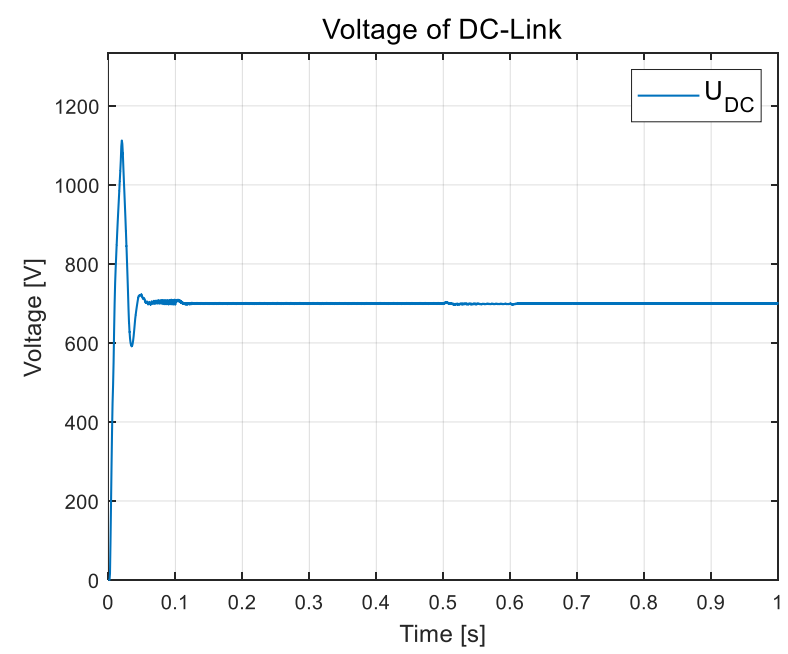

Figure 9: DC Voltage on DC-Link

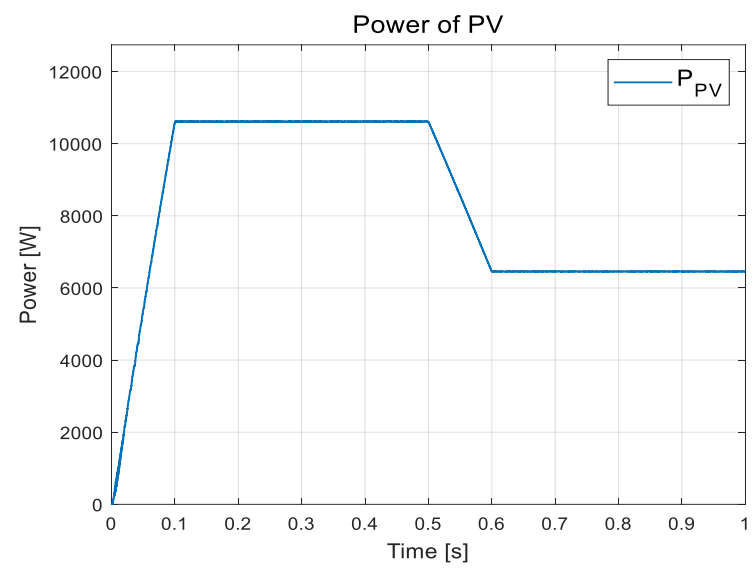

Figure 8: Panel Capacity

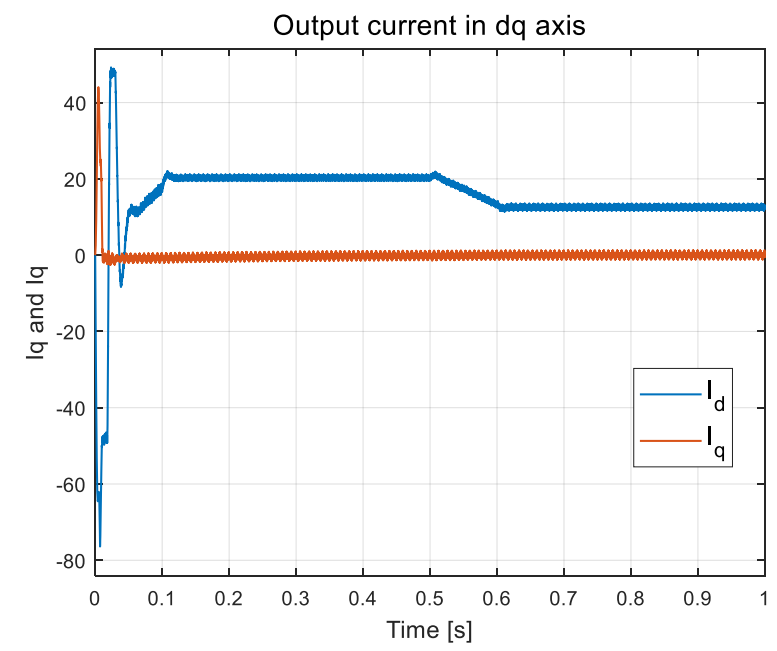

Figure 10: The Converter Output Current on the dq axis 


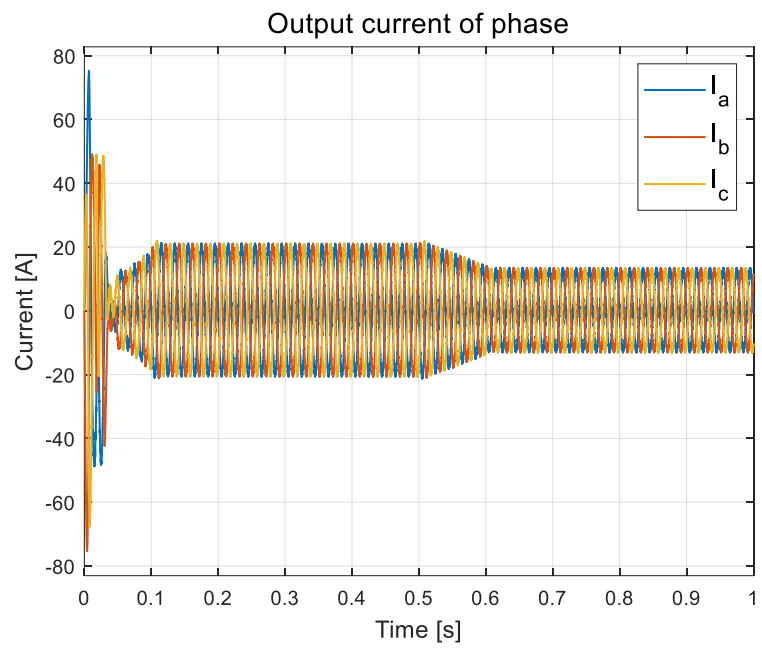

Figure 11: The Output Current of the Converter

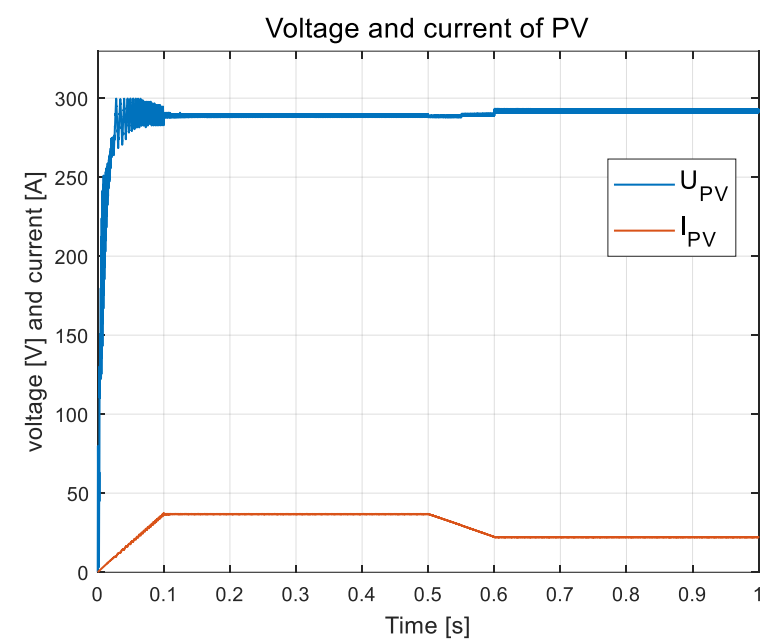

Figure 12: Current and Voltage of the PV

\section{Comments}

The power of the panels depends on the variation of the light intensity impacting the panel, as shown in Figures 7 and Figure 8. The ability to track to the maximum power point of the $\mathrm{P} \& \mathrm{O}$ algorithm used in the paper ensures stability and impact time of the system, as depicted in Figure 8. Oscillation with step-change dV $=1 \mathrm{~V}$ is acceptable. The MPPT unit works correctly under conditions of varying radiation intensity. The current component iq characterizing the reactive power is kept steady around zero. Therefore, a grid-connected PV system is introduced without causing any adverse effects to the grid, such as voltage distortion or phase shift. The current component id representing the power consumption transmitted into the grid varies depending on the input panel capacity.

Figure 10 shows that the current controller virtually eliminates the coupling effect. The standard sinusoidal threephase current is provided by the SVM PWM modulation method at 5kHz, as shown in Figure 11. At this frequency, the power circuit can use various inexpensive popular switches, providing high practical applicability. The variation of the panel current and voltage is shown in Figure 12.

\section{CONCLUSIONS}

This paper uses $\mathrm{P} \& \mathrm{O}$ algorithm to control the boost converter to track the maximum power point of solar panels. The control method on the dq coordinate system for the grid-connected inverter has achieved the separation of the control channel separately from two current components, characteristic of power consumption and reactive power. The simulation results have proven the functional ability of the system.

\section{ACKNOWLEDGEMENTS}

This research was supported by Research Foundation funded by Thai Nguyen University of Technology.

\section{NOTATION LIST}

$\mathrm{I}_{\mathrm{PH}} \quad$ : Photoelectric current

IS : Saturated current

$q=1.6 \times 10-19 C:$ Atomic charge 
$\mathrm{k}=1.38 \times 10-23 \mathrm{~J} / \mathrm{K}$ : Boltzmann's constant

$\mathrm{T}_{\mathrm{C}} \quad$ : Working temperature of the photovoltaic cell

A : Ideal constant of semiconductor materials

$\mathrm{R}_{\mathrm{SH}} \quad$ : Parallel resistance (shunt)

RS : Serial resistance

$I_{S C}^{S T C} \quad$ : Short-circuit current of the photoelectric cells at $25^{\circ} \mathrm{C}$ and $1 \mathrm{~kW} / \mathrm{m}^{2}$

$\mathrm{T}_{\mathrm{PV}} \quad$ : The working temperature of the photovoltaic cells $\left({ }^{0} \mathrm{C}\right)$

$\mathrm{K}_{\mathrm{i}} \quad$ : Short-circuit current temperature coefficient of photovoltaic cells

$\lambda^{S T C} \quad:$ Solar radiation $1 \mathrm{~kW} / \mathrm{m}^{2}$

$\mathrm{I}_{\mathrm{RS}} \quad$ : Current flows through the internal parallel resistance $\mathrm{R}_{\mathrm{SH}}$

$E_{\lambda} \quad$ : Distance energy of semiconductors of photovoltaic cells

$T_{P V}^{S T C} \quad$ : Standard temperature of the photovoltaic cell ${ }^{0} \mathrm{C}$.

\section{REFERENCES}

1. Petreuş, D., Fărcaş, C., \& Ciocan, I. (2008). Modelling and simulation of photovoltaic cells. Acta Technica NapocensisElectronics and Telecommunications, 49(1), 42-47.

2. Sheng, X., Broderick, L. Z., \& Kimerling, L. C. (2014). Photonic crystal structures for light trapping in thin-film Si solar cells: Modeling, process and optimizations. Optics Communications, 314, 41-47.

3. Bouzidi, K., Chegaar, M. A. B. A., \& Bouhemadou, A. (2007). Solar cells parameters evaluation considering the series and shunt resistance. Solar Energy Materials and Solar Cells, 91(18), 1647-1651.

4. Chegaar, M., Hamzaoui, A., Namoda, A., Petit, P., Aillerie, M., \& Herguth, A. (2013). Effect of illumination intensity on solar cells parameters. Energy Procedia, 36, 722-729.

5. Bouzidi, K., Chegaar, M., \& Aillerie, M. (2012). Solar cells parameters evaluation from dark IV characteristics. Energy Procedia, 18, 1601-1610.

6. Chiang, S. J., Shieh, H. J., \& Chen, M. C. (2008). Modeling and control of PV charger system with SEPIC converter. IEEE Transactions on industrial electronics, 56(11), 4344-4353.

7. Patel, H., \& Agarwal, V. (2008). MATLAB-based modeling to study the effects of partial shading on PV array characteristics. IEEE transactions on energy conversion, 23(1), 302-310.

8. Paulescu, M., Paulescu, E., Gravila, P., \& Badescu, V. (2012). Weather modeling and forecasting of PV systems operation. Springer Science \& Business Media.

9. Veerachary, M., Senjyu, T., \& Uezato, K. (2003). Maximum power point tracking of coupled inductor interleaved boost converter supplied PV system. IEE Proceedings-Electric Power Applications, 150(1), 71-80.

10. Hasaneen, B. M., \& Mohammed, A. A. E. (2008, March). Design and simulation of DC/DC boost converter. In 2008 12th International Middle-East Power System Conference (pp. 335-340). IEEE.

11. Elshaer, M., Mohamed, A., \& Mohammed, O. (2010, November). Smart optimal control of DC-DC boost converter in PV 
systems. In 2010 IEEE/PES Transmission and Distribution Conference and Exposition: Latin America (T\&D-LA) (pp. 403-410). IEEE.

12. Abdel-Rahim, O., Orabi, M., Abdelkarim, E., Ahmed, M., \& Youssef, M. Z. (2012, February). Switched inductor boost converter for PV applications. In 2012 Twenty-Seventh Annual IEEE Applied Power Electronics Conference and Exposition (APEC) (pp. 2100-2106). IEEE.

13. Kim, S. K., Jeon, J. H., Cho, C. H., Kim, E. S., \& Ahn, J. B. (2009). Modeling and simulation of a grid-connected PV generation system for electromagnetic transient analysis. Solar Energy, 83(5), 664-678.

14. Dubey, S., \& Tiwari, G. N. (2008). Thermal modeling of a combined system of photovoltaic thermal (PV/T) solar water heater. Solar energy, 82(7), 602-612.

15. Villalva, Marcelo G., and Ernesto Ruppert. "Analysis and simulation of the P\&O MPPT algorithm using a linearized PV array model." 2009 35th Annual Conference of IEEE Industrial Electronics. IEEE, 2009.

16. Femia, N., Petrone, G., Spagnuolo, G., \& Vitelli, M. (2004, June). Optimizing sampling rate of P\&O MPPT technique. In 2004 IEEE 35th Annual Power Electronics Specialists Conference (IEEE Cat. No. 04CH37551) (Vol. 3, pp. 1945-1949). IEEE.

17. Razali, N. M., \& Rahim, N. A. (2011, June). DSP-based maximum peak power tracker using P\&O algorithm. In 2011 IEEE Conference on Clean Energy and Technology (CET) (pp. 34-39). IEEE.

18. Li, B., Tian, X., \& Zeng, H. (2011, July). A grid-connection control scheme of PV system with fluctuant reactive load. In 2011 4th International Conference on Electric Utility Deregulation and Restructuring and Power Technologies (DRPT) (pp. 786790). IEEE.

19. Kazmierkowski, M. P., Jasinski, M., \& Wrona, G. (2011). DSP-based control of grid-connected power converters operating under grid distortions. IEEE Transactions on Industrial Informatics, 7(2), 204-211.

20. Martins, D. C. (2013). Analysis of a three-phase grid-connected PV power system using a modified dual-stage inverter. International Scholarly Research Notices, 2013.

21. Belfedal, C., Moreau, S., Champenois, G., Allaoui, T., \& Denai, M. (2008). Comparison of PI and Direct Power Control with SVM of Doubly Fed Induction Generator. Istanbul University-Journal of Electrical \& Electronics Engineering, 8(2), 633-641. 
